\title{
El país que no existió: tiempo y narración en $O$ Brasil é bom, de André Sant'Anna
}

\section{The country that did not exist: time and narration in $O$ Brasil é bom, by André Sant'Anna}

\section{O país que não existiu: tempo e narração em $O$ Brasil é bom, de André Sant'Anna}

\author{
Rodrigo Gomes de Araujo* \\ Universidad Autonoma Metropolitana Azcapotzalco, UAM \\ rodrigo.ufprmec@gmail.com
}

\begin{abstract}
RESUMEN: La literatura expresa ideologías y temporalidades, obras ficcionales pueden plantear sociedades distintas de las que vivimos. En este ensayo analizo cómo, en el libro O Brasil é bom (2014), André Sant'Anna critica la coyuntura política a la vez en que realiza una proyección distinta de su país. En esa discusión, la temporalidad es el elemento que da profundidad histórica y política al libro. Realizo el análisis en cuatro pasos: primero presento al escritor según su lugar social de enunciación; posteriormente explico la propuesta estética del libro; en un tercer momento discuto la historicidad de la obra, en diálogo con Reinhart Koselleck, a partir de la relación temporal entre experiencia y expectativa; y finalmente analizo las orientaciones ideológicas de Sant'Anna, para evidenciar cómo su propuesta estética se desdobla en intencionalidades políticas.
\end{abstract}

PALABRAS CLAVE: Literatura contemporánea. Historicidad. Experiencia. Expectativa. Siglo XXI.

ABSTRACT: Literature expresses ideologies and temporalities, fictional works could pose different societies from the ones we live in. In this essay, I analyze how André Sant'Anna in his book O Brasil é bom (2014) criticizes the political circumstances while making a different projection of his country. In that discussion, temporality is the element that gives the book historical and political depth. I do this analysis in four steps: I first introduce the author according to his social place of enunciation. Then I explain the aesthetic proposal of the book. In third place, I discuss the historicity of the work, in dialogue with Reinhart Koselleck, based on the temporal relationship between experience and expectation. Finally, I analyze the ideological orientations of Sant'Anna to show how his aesthetic proposal unfolds into political intensions.

KEYWORDS: Contemporary literature. Historicity. Experience. Expectation. $21^{\text {st }}$ Century.

RESUMO: A literatura expressa ideologias e temporalidades, obras ficcionais podem propor sociedades distintas das que vivemos. Neste ensaio analiso como, no livro $O$

\footnotetext{
* Doutorando em Historiografia pela Universidad Autónoma Metropolitana Azcapotzalco, UAM-A, México.
} 
Brasil é bom (2014), André Sant'Anna critica a conjuntura política ao mesmo tempo em que realiza uma projeção distinta de seu país. Nessa discussão, a temporalidade é o elemento que confere profundidade histórica e política ao livro. Realizo a análise em quatro passos: primeiro apresento o escritor de acordo com seu lugar social de enunciação; posteriormente explico a proposta estética do livro; num terceiro momento discuto a historicidade da obra, em diálogo com Reinhart Koselleck, a partir da relação temporal entre experiência e expectativa; e finalmente analiso as orientações ideológicas de Sant'Anna, para evidenciar como sua proposta estética se desdobra em intencionalidades políticas.

PALABRAS-CHAVE: Literatura contemporânea. Historicidade. Experiência. Expectativa. Século XXI.

André Sant'Anna es un escritor y músico brasileño que se dedica profesionalmente a la publicidad. Nacido en 1964, hijo del consagrado escritor Sérgio Sant'Anna, publicó su primer libro, Amor, en 1998. El autor cuenta que lo escribió como catarsis en las horas libres cuando trabajaba en agencias publicitarias (MALERONKA, 2014), su padre lo interpretó como una obra distinta y recomendó su publicación en una pequeña editorial independiente. El libro es una edición de autor, de quinientos ejemplares, que si bien fue pagada por el escritor, él mismo reconoce que la influencia paterna fue importante para su entrada en el mercado editorial (VASCONCELOS, 2007, p. 84-85). André Sant'Anna envió varios ejemplares a periódicos, críticos y escritores, posiblemente conocidos por su padre, y tuvo una buena repercusión, con elogios del escritor Bernardo Carvalho (1998) y de la crítica Flora Süssekind (1999), por ejemplo, dos importantes sujetos del medio literario brasileño.

Su segundo libro, Sexo, del año siguiente, publicado por una editorial más grande y comercial, ya no fue pagado por él y también se destacó entre la crítica. Sant'Anna pasó a tener más visibilidad con su inclusión en el libro Os cem melhores contos brasileiros do século (2000), organizado por Ítalo Moriconi, y posteriormente en Geração 90: os transgressores (2003), con organización de Nelson de Oliveira. Ambos libros, publicados por grandes editoriales, aspiraban a presentar un panorama de la producción literaria de generaciones recientes y destacar los escritores en el escenario nacional.

Posteriormente, Sant'Anna participó de un proyecto con Companhia das Letras, una de las editoriales más prestigiosas de Brasil, lo que resultó en la larga novela $O$ 
paraíso é bem bacana de 2006. El libro puede ser considerado una excepción por su proceso editorial ambicioso, con un escritor poco conocido del público, para la realización de una obra de más de cuatrocientas páginas, lo que aumenta su costo y dificulta la circulación en el mercado (VASCONCELOS, 2007, p. 85).

El propio Sant'Anna no se consideraba un escritor hasta que empezó a tener reconocimiento en el medio literario (MALERONKA, 2014). A principio, lo que llamó la atención fue el lenguaje empleado por el autor, considerado algo diferente en su coyuntura (SCHOLLHAMMER, 2009, p. 70-71), lo que ya había observado su padre. Independientemente de las virtudes de la obra, no se debe desconsiderar el papel paternalista que Sérgio Sant'Anna tuvo para la inserción del hijo en el mercado editorial y también para la recepción por escritores y críticos. El prestigio del padre, y sus contactos en el medio, adquiridos a lo largo de décadas, son un elemento importante para la entrada de André Sant'Anna al medio literario y luego pudo ser reconocido por pares debido a la particularidad de su escritura. Aunado al apoyo paterno está la visibilidad adquirida con la inclusión de sus textos en los dos libros colectivos, obras con repercusión nacional. También todo el mecanismo de difusión de las grandes editoriales, principalmente Companhia das Letras, y las críticas publicadas en periódicos prestigiosos, son elementos que conceden un carácter de relevancia a la obra en el medio literario.

Reforzado por ese aparato literario, como el apoyo paterno, la difusión y el reconocimiento por la crítica, Sant'Anna declara que al principio no pensaba en destinatarios para sus textos, pero cuando empezó a tener visibilidad pasó a escribir direccionado al público especializado en literatura, principalmente a los que sus obras anteriores habían impresionado (ENTRE-VISTA, 2008). De ese modo, busca propuestas estéticas no convencionales, basado en repeticiones, lenguajes comunes e incluso vulgares, lo que resultó en críticas que lo acusaron de utilizar un exceso de groserías para ocultar la falta de talento (TEIXEIRA, 2006), repercusión que para el escritor es una actitud conservadora y sin valor para admitir diferentes propuestas estéticas (SANT'ANNA, 2007). ${ }^{1}$

${ }^{1}$ Los textos del debate entre Sant'Anna y los críticos acerca del tema están reunidos en los anexos de la tesis (ALMEIDA, 2012, p. 112-119). 
En O Brasil é bom, de 2014, Sant'Anna presenta una serie de narraciones cortas, cuya mayoría ya había sido publicada en periódicos. Marcado por la irreverencia que caracteriza su escritura, el libro es compuesto en tres partes complementarias con características distintas: la primera pautada en el presente, con monólogos de personajes, la segunda en que se destacan las proyecciones de futuro y la tercera es conformada por narraciones autoficcionales ubicadas en el pasado.

En la primera parte, con diecisiete narraciones cortas que en conjunto ocupan cerca un cuarto del libro, los textos son en su mayoría monólogos con repeticiones constantes, basadas en lugares comunes. En el conjunto hay una diversidad de personajes y situaciones actuales: un pastor pide dinero a los fieles, alguien manifiesta su desprecio a las clases sociales inferiores, otro personaje aconseja que seamos deshonestos, violentos y corruptos, narradores que elogian la dictadura militar, exaltan un supuesto avance económico y el éxito en el futbol, otros que idolatran al país sin considerar los problemas sociales, un hombre critica la banalidad del consumismo y del sexo, e incluso hay un texto narrado por Jesucristo, en que él, molesto con la banalidad de los religiosos, decide acabar con la existencia humana.

El panorama de ese primer bloque revela personajes en el presente, completamente inmersos en sus ideas, incapaces de observar o aceptar la pluralidad social. Los textos marcados por ironía, o mismo cinismo, son construidos con lenguaje coloquial, como la mezcla de plural y singular, peculiar en la oralidad brasileña, y dibujan una coyuntura fácilmente identificable, no solamente de Brasil sino internacional, en que las relaciones económicas ordenan la sociedad.

El enunciado del pastor, que intenta convencer a los fieles a que paguen a la Iglesia para alcanzar la salvación en "O futuro vai ser bom" es muy representativo:

Vai, vai ser [bom o futuro], sim, e também a nível internacional. Basta
que todos juntos, de mãos dada, unidos num só ideal, façamos a
nossa parte e, assim, possamos construir um mundo melhor para os
nossos filhos e netos no futuro. Cabe a cada um de nós, a nível
internacional, fiscalizar com responsabilidade aqueles que estão ao
seu redor, aqueles estrangeiro que vem pro seu país roubar os
emprego, essas mulher que confunde liberdade com libertinagem e
usa saia muito curta, esses livro que dão pras criança nas escola com
imagens inadequadas de índio pelado, esses cara que fuma cigarro e
desrespeita os direito do próximo que não quer sentir cheiro de cigarro.
O direito de um acaba quando começa o direito do outro, e vamos
mudar de assunto que esses papo de guerra, a nível internacional, que
no Brasil não tem guerra, é muito negativo e a gente tem que pensar
tudo positivo o tempo todo, ainda mais quando o futuro está chegando 
e uma nova era de paz está nascendo (SANT'ANNA, 2014, posición 122).

En el fragmento están presentes tanto la propuesta estética del libro, como los disparates evocados por los personajes. El pastor que empieza con la posibilidad de un futuro mejor a partir de la unión, sigue con un discurso intolerante, prejuicioso, xenófobo y machista, que contradice la diversidad del vínculo social que el propio personaje plantea.

Contradicción, ironía y sarcasmo son elementos que predominan en la primera parte del libro. En "O Brasil não é ruim", por ejemplo, un texto extremadamente irónico que critica el sistema político brasileño, el uso de la palabra "no" ("não") repetidamente, en cada frase a lo largo de la narración, revela justo lo opuesto de lo que declara. Así, reprueba el absurdo de negar lo obvio de una política basada en desigualdad y violencia, y concluye con cinismo: "É por isso que o Brasil é bom." (SANT'ANNA, 2014, posición 98). También en la narración titulada "O brasileiro é bom", hay un vertiginoso flujo de lugares comunes, con un nacionalismo que atribuye características positivas al pueblo como si fueran intrínsecas al país. En "Comentário na rede sobre tudo o que está acontecendo por aí" un conservador inflexible se posiciona contra los derechos humanos, culpa la televisión, es xenófobo y nacionalista, exalta la violencia y el exterminio de todo que es diferente. El enaltecimiento de esos narradores es pura ironía, sarcasmo presente desde el título del libro, O Brasil é bom, que expresa su exacto contrario, un país que no parece tener nada bueno.

La segunda parte es conformada por "Lodaçal", que ocupa cerca de un cuarto del libro, la narrativa cambia y ya no es un personaje en primera persona que ofrece su punto de vista sobre un contexto presente y sin perspectivas, sino un narrador extradiegético que presenta dos niños en esa coyuntura. Los personajes viven en Brejo da Cruz, en intertextualidad con la canción de Chico Buarque en que la pobreza era tanta que los niños se alimentaban de luz, Sant'Anna describe un minúsculo pueblo de cuatro o cinco casas, alrededor de una cancha de futbol. Brejo da Cruz es un charco en completa miseria en que llueve todo el tiempo. Chiquinho y Toninho, niños acostumbrados a no comer, siquiera sienten hambre, prefieren fumar marihuana e imaginar futuros en un mundo que no conocen. 
Los dos niños completamente ignorantes y privados de todo, si bien no tienen ni mismo lenguaje para comprender lo que piensan, empiezan a imaginar un mundo de múltiples futuros poblados por diversas versiones de ellos mismos.

O Toninho nunca tinha visto uma televisão naquela vida que o Toninho não vivia, naquela vida que não havia, mas o Toninho estava vendo televisão, televisão colorida, TV a cabo digital, som estéreo, um jogo de futebol em um campo com círculo central, um campo de grama, e o Toninho nunca tinha visto grama, nunca tinha visto futebol [...] e o Toninho via, ele lá, o Toninho, correndo com a bola que ele não sabia como era, o Toninho, tão primitivo, indo para o gol com a bola... Era o Toninho correndo com a bola, que ele, o Toninho, não sabia o que era, correndo para o gol, que ele, o Toninho, não sabia o que era, na televisão, que ele, o Toninho, não sabia o que era, o Toninho sentindo uma vida interior, a maior loucura (SANT'ANNA, 2014, posición 783).

En todas las proyecciones predomina el pesimismo, aunque salgan de Brejo da Cruz, los personajes no encuentran una vida digna y terminan siempre marginados, alimentándose con restos de comida mezclados con basura y excrementos.

La narración culmina en una escena en que varias de sus versiones futuras se agreden, un Chiquinho policía aplasta el cráneo de un Chiquinho niño indigente, ayudado por otros Chiquinhos y Toninhos. El policía asesina otras versiones de los personajes, todavía niños, y concluye haberles hecho un favor, por liberarlos de una subsistencia tan desgraciada. Los futuros descritos dibujan imágenes fragmentadas de un país miserable, cultural y económicamente.

Después de "Lodaçal", sigue una corta narrativa con una lírica basada en la interconexión de pequeñas oraciones. Empieza la tercera parte y Sant'Anna presenta cuatro narraciones autoficcionales, los textos de denuncia de un país absurdo ceden lugar a las memorias de un narrador, como si fuera una novela de formación. En este bloque, un narrador André dice ser George Harrison y también Glauber Rocha, entre otros personajes, ídolos a quien un el joven protagonista aspira a ser. Las experiencias personales del escritor sirven al narrador, André, George, Glauber, y se entrecruzan con eventos que marcaran al país.

Así, "A história da revolução" narra la relación del personaje con la dictadura militar, y se refiere irónicamente al golpe de estado como si fuera una revolución, usando la palabra "revolução" seguida de un "(rá rá rá)" que indica una carcajada. La historia familiar es envuelta a los eventos nacionales y el narrador crece sin entender 
las orientaciones políticas de derecha de sus abuelos alineados al gobierno militar y los padres disidentes de izquierda.

En una confusión ideológica, el joven narrador empieza a tener contacto con referencias culturales de sus padres, que son importantes para su crecimiento personal. A partir de esas referencias, el personaje hace las proyecciones a sí mismo y tiene por un lado George Harrison como un modelo de músico hipie y por otro Glauber Rocha como un cineasta político y revolucionario. Con esas dos figuras que marcaron su formación, el personaje construye su visión del mundo, y en los años de 1980, el adolescente que vive el final de la dictadura militar, idealiza un porvenir.

E na nossa turma do São Vicente, do Posto 9, tinha a Mariana, que é neta do Vinicius de Moraes, que tinha uns treze anos e fazia topless, lindona, e na visão de mundo do Glauber Rocha que o George Harrison estava desenvolvendo, uma espécie de ideologia, o Macalé empinando pipa, a Mariana de treze anos fazendo topless, o Gabeira de tanga rosa e a Isabel grávida lindona eram peças importantes de um Brasil que o George Harrison achava que ia começar dali a pouco e que ia ser o Brasil do Glauber Rocha, do Darcy Ribeiro, do Jorge Mautner (SANT'ANNA, 2014, posición 1696-1705).

La mezcla cultural vivida por el personaje, evocada por las amistades y la experiencia con músicos, cineastas y pensadores sociales, genera la expectativa de un futuro con diversidad cultural y libertades individuales. Sin embargo, esta proyección de futuro no se concreta con la redemocratización, y el personaje frustrado percibe que solamente queda una mentalidad popular de intolerancia, que exalta la dictadura, opuesta a la diversidad y a la libertad aspiradas por él. Y así concluye la narración:

o Brasil do Glauber Rocha e do Darcy Ribeiro e o amálgama brasileiro que o Mautner diz haver, essas porra, não têm a menor possibilidade, não vai rolar, Glauber, e o Índice de Desenvolvimento Humano é baixíssimo, e de vez em quando o George ouve o papo de algum babaca filho da puta no ônibus para cidadãos com baixo Índice de Desenvolvimento Humano ou na mesa do restaurante por quilo, na mesa ao lado, um desses babacas que trabalham numa firma filha da puta, dizendo que bom era na época da ditadura, ou que o que atrapalha é essas porra de direitos humanos que vêm aqui é pra soltar os bandido, porque em bandido tem é que dar porrada, tem é que ir pra pena de morte essas porra (SANT'ANNA, 2014, posición 17321741). 
Esa ruptura en la expectativa, vivida por el autor y ficcionalizada en su escritura, sigue como tema central en la tercera parte de libro. En "A história do rock" es la experiencia estética con la música lo que lleva el personaje a rememorar su infancia y adolescencia con una narración que llega a ser nostálgica. Es con la descubierta del disco Magical Mystery Tour de los Beatles en la infancia que el narrador pasa a identificarse con George Harrison y se vuelve eclético con los géneros musicales, apreciando el jazz experimental de Miles Davis, el rock progresivo de Pink Floyd, hasta las canciones románticas de Roberto Carlos. Esos elementos culturales, entre diversos otros, mencionados en el texto fueron formadores de una visión del mundo en que la pluralidad es uno de los principales elementos. Pero la narración termina también en desencanto, declarando que todos se volvieron conservadores, retrógrados, y el sueño del rock como liberación no se concretó.

La misma relación con la música y la experiencia estética está en $A$ história da Alemanha. En esta última narración del libro, el enfoque está en las experiencias culturales y políticas del joven narrador que llega a Alemania unificada, justamente en los primeros días después de la caída del muro de Berlín. La multiplicidad es evidenciada por el torbellino de referencias culturales, como las numerosas descubiertas musicales, pero principalmente por poder vivenciar la reunificación de un país que había estado dividido, lo que le genera encanto y la ilusión de que Brasil también podría alcanzar la integración de las pluralidades culturales.

E o Brasil seria lindo, o Brasil afro-índio-europeu do Mautner, o Brasil Frátria que o Caetano sugeriu, o Brasil onde haveria a Revolução Eztétyka do Glauber Rocha, mas o Glauber Rocha já havia morrido fazia dez anos e, mesmo com a redemocratização e o impeachment do Collor, o Brasil era, e é até hoje, um lugar onde as pessoas só falam em dinheiro, só pensam em dinheiro e acham que o primeiro mundo é um lugar onde tudo é proibido. E o Brasil é a sexta economia do mundo e é cheio de criança pedindo dinheiro nas ruas, e fica essa impressão de que o Brasil é grandes-merda só porque não deve mais dinheiro ao FMl e todo mundo tem carro e sai por aí, por lá, atropelando as pessoas, provocando uns acidentes cheios de sangue, construindo uns hotéis/resorts cafonas, emporcalhando tudo onde antes havia aqueles litorais do Dorival Caymmi e do Ari Barroso (SANT'ANNA, 2014, posición 2393-2403).

Al regresar a su país, el narrador únicamente encuentra un sitio aún más inmerso en un sistema basado en relaciones financieras. El personaje, decepcionado, 
interpreta que la cultura que ha vivido en Alemania unificada es lo que más se acerca a sus expectativas. Y un Brasil culturalmente democrático, que valora la pluralidad y las libertades individuales, proyectado al final de la dictadura militar, no pasó de un sueño. Las últimas frases del libro son icónicas de esa desilusión y expresan la ironía del título O Brasil é bom:

Vou dizer uma coisa pra você, uma coisa que, no país da Copa do Mundo, dos Jogos Olímpicos e das instituições de espancar crianças seria considerado uma blasfêmia absoluta: a Alemanha é muito melhor do que o Brasil. Pode crer. (SANT'ANNA, 2014, posición 2491-2430).

\section{3}

Según Reinhart Koselleck experiencia y expectativa son indisociables de cualquier reflexión sobre el tiempo, esas dos categorías están ubicadas en todas las coyunturas. La relación con el tiempo se expresa a través de la experiencia que proviene del pasado y de la expectativa que proyecta las posibilidades de futuro (KOSELLECK, 1993, p. 337-338). De ese modo, entender la interconexión entre experiencia y expectativa posibilita la reconstrucción de la historicidad de determinado momento histórico.

Experiencias proyectan expectativas, y si las vivencias cambian también las proyecciones de futuro serán distintas. Asimismo, nuevos ideales de futuro conllevan a reinterpretaciones del pasado y a la creación de nuevas experiencias. De acuerdo con Koselleck, "la tensión entre experiencia y expectativa es lo que provoca de manera cada vez diferente nuevas soluciones, empujando de ese modo y desde sí misma al tiempo histórico" (KOSELLECK, 1993, p. 342).

Esas dos categorías ayudan a interpretar la propuesta estética de O Brasil é bom y conceden perspectivas temporales y políticas al libro. La expectativa de que Brasil pudiera desarrollarse como un país culturalmente democrático, con respeto a las libertades individuales y a la diversidad, como pensaban el cineasta Glauber Rocha, el antropólogo Darcy Ribeiro y el músico Jorge Mautner, entre otros nombres citados en el libro, jamás se concretó. El lugar con que soñó André Sant'Anna, y también su personaje autoficcional, presentado en la tercera parte de la obra, es un país que solamente existió como utopía. La historicidad de esa perspectiva de un país multicultural, cultivada cuando Brasil estaba por empezar el proceso de 
redemocratización, en el comienzo de los años de 1980, es lo que estructura todo el libro.

Rocha, Ribeiro y Mautner, reiteradamente mencionados en la tercera parte de O Brasil é bom, cada uno en su campo de actuación, tenían en común la esperanza de que el futuro del país sería una democracia cultural y la particularidad que destacaría a Brasil entre otras naciones era justamente su diversidad.

Desde el comienzo de la dictadura militar, en la década de 1960, Glauber Rocha defendía una ruptura con el racionalismo europeo, interpretado como forma de dominación ideológica que mantenía la desigualdad social, para enfocarse en las culturas amerindias y africanas, desarrollando así una mezcla cultural (ROCHA, 2013 [1971]). Según el cineasta era necesario asumir un posicionamiento tanto estético como ético, hacer la denuncia social a través del arte, discutiéndola como problema político (ROCHA, 2013 [1965]).

Entre los años 1960 y 1980, también el antropólogo Darcy Ribeiro, que dedicó la mayor parte de su carrera intelectual y política a elaborar una imagen del futuro no solamente a Brasil sino a Latinoamérica (KOZEL, 2019, p. 130-132), defendía el abandono de los proyectos elitistas de desarrollo. Para Ribeiro, debido a la mezcla cultural y étnica, los latinoamericanos éramos una civilización emergente, que una vez liberados de los modelos europeos construiríamos nuevas formas de sociedad, más humanas y menos determinadas por relaciones económicas (RIBEIRO, 1984, p. 26$37)$.

En la primera mitad década de 1980, esas formas de sociedad no capitalistas proyectadas por Ribeiro, también eran defendidas por Jorge Mautner. El músico argumentaba que la verdadera revolución sería construir una vida en que la economía fuera irrelevante, en que relaciones financieras no importaran, vivir "como gato", sin preocuparse con nada, escribía Mautner (1983), con esperanza, dos años antes de que se acabara la dictadura militar. Igualmente defensor de la pluralidad, interpretaba que la mezcla cultural y étnica brasileña conformaban una amalgama capaz de unir lo erudito, lo psicodélico y lo popular, y esa fusión llevaría el país a un futuro prometedor.

Los tres puntos de vista, que conforman un conjunto de perspectivas en $O$ Brasil é bom, tienen en común una expectativa optimista, que enunciaba un futuro en que la diversidad cultural sería el elemento diferencial y llevaría Brasil, y América Latina, al desarrollo y a organizaciones sociales no capitalistas. La historicidad de esas perspectivas está en el modo esperanzado de pensar, en plantear un futuro que 
empezaba a anunciarse y debería ser mejor que la represión de la dictadura militar. Este no es un proyecto nuevo, pues retoma la ideología pluralista y aglutinadora del Movimiento Antropofágico de la década de 1920, y la idea de construir un país a partir de la integración cultural, ha estado presente de distintas maneras desde de la Independencia (SCHWARZ, 1987, p. 29-38).

En los ideales de Rocha, Ribeiro y Mautner, proyecciones de futuro para el fin de la dictadura militar, las relaciones serían basadas en la pluralidad cultural y el convivio humano. Como lo escribió Ribeiro:

Hombres y mujeres, al mismo tiempo a amarse mutuamente de forma más profunda y placentera, se tornan menos represivos para las minorías que tienen talentos alternativos, con otras formas de relación y satisfacción (RIBEIRO, 1987).

Utopía que no se concretó, país que no existió. El propio André Sant'Anna ha declarado que esas propuestas lo llenaron de expectativas para el futuro.

\begin{abstract}
Quando eu era adolescente, 14, 15 anos, me mudei para o Rio de Janeiro, em 1979. Logo em 1980 teve aquele tal verão da abertura. Eu ia à praia, ali no posto nove, e ficava vendo, ali, o Glauber Rocha fazendo discurso. Os exilados voltando, começando a ter a primeira eleição para governador, Darcy Ribeiro [era candidato]... foi uma época em que vi o mundo com uma felicidade muito grande, vi o Brasil como uma coisa muito legal. Vai ser um país muito grande, porra, vai ser muito legal; vou viver uma coisa maravilhosa, meu país onde eu vivo e tal. $E$ eu acho que não foi nada disso (SANT'ANNA apud MALERONKA, 2014).
\end{abstract}

La frustración de las expectativas de una sociedad multicultural, libertaria y humanista cambia las perspectivas de Sant'Anna, Brasil de la redemocratización no llega a ser el país que el escritor desea, pues no se respetan las libertades individuales, tampoco los derechos colectivos. Y Alemania reunificada, en que el autor vivió en un periodo de su vida, pasa a ser su modelo de nación. Su libro termina justamente con un comparativo que destaca la superioridad alemana en relación a Brasil. Sant'Anna al discutir su propia obra declara: "O Brasil é bom foi minha discussão política, minha tese de que o Brasil do Glauber [Rocha] e do Darcy Ribeiro não está rolando" (SANT'ANNA en MALERONKA, 2014). El libro es justamente un planteamiento político realizado a través del arte, como proponía Rocha. 
La caída del muro de Berlín en 1989 es interpretada por François Hartog como ruptura política, momento en que, según el filósofo, las ideologías perdieron la capacidad de formar grandes perspectivas colectivas, lo que generó un cambio en los conceptos de tiempo en el Occidente, con un alargamiento del presente y la anulación de las proyecciones de futuro (HARTOG, 2013, p. 140-148). Sin embargo, el cambio político no necesariamente significa el abandono de proyectos ideológicos (SIMON, 2016). La interpretación de Hartog es generalizadora, centrada únicamente en Europa, e ignora que en la actualidad, a pesar de la predominancia de una temporalidad pautada por el presente, puedan existir otras formas de relacionarse con el tiempo (LORENZ, 2019, p. 32-36). En vez de la perspectiva política europea, un abordaje cultural formulado desde una mirada de otro país, por ejemplo, puede revelar que después de la caída del muro siguieron existiendo expectativas colectivas de futuro.

El evento histórico de la reunificación alemana, vivenciado por André Sant'Anna, queda plasmado en sus narraciones autoficcionales a partir de una mirada cultural. En vez de trauma que estanca el tiempo en el presente, sin posibilidad de mirar al pasado o proyectar futuro, como interpretó Hartog desde una perspectiva política, la experiencia del escritor en 1990 en Alemania, de cierta forma, concreta su sueño de integración cultural. La fascinación vivida en aquel país, narrada en el libro y reiterada en una entrevista (MALERONKA, 2014), ayuda a definir su ideal del mundo y se suma como experiencia práctica a las discusiones teóricas de Rocha, Ribeiro y Mautner.

En una Alemania multicultural, que quizá haya sido más la ilusión de un joven repleto de perspectivas que una realidad concreta, Sant'Anna ve la posibilidad de una sociedad que respeta las libertades individuales, con una política que no está basada únicamente en las relaciones económicas. El cambio en la experiencia, genera un cambio de expectativas, como lo escribió Koselleck. Es en Alemania, vista con encanto en su juventud, que el escritor ve la posibilidad de realización de su proyecto de futuro. La reunificación del país, que para Hartog significa ruptura política y fin del sueño de un futuro colectivo, para Sant'anna es justo lo opuesto, es la realización de su ideal de una sociedad libertaria y culturalmente plural. Lo que ocasiona la ruptura de sus expectativas es el regreso a Brasil, cuando el autor se da cuenta de que su país tomó el camino inverso, no de la pluralidad cultural y de la libertad, sino de una hegemonía de pensamientos conservadores y retrógrados. 
Sant'Anna ha trabajado en propaganda publicitaria por varios años para partidos de distintas orientaciones y dice haber aprendido mucho sobre el funcionamiento de la política, incluso considera poder abstraer el trabajo publicitario de su orientación personal. Para él, los conceptos de izquierda y derecha ya no funcionan actualmente, por lo que es necesario buscar una tercera vía que no esté basada en la economía. Según el escritor, el "equilíbrio sociopolítico está na harmonia entre "liberdades individuais" e "direitos e deveres coletivos"' (SANT'ANNA en BRESSANE, 2014). También declara haber recuperado la esperanza en los cambios políticos en el comienzo del siglo XXI, con la llegada del Partido dos Trabalhadores al poder, pero el único avance que observó con el gobierno Lula fue una pequeña ascensión económica y social de los más pobres. En su interpretación, el resultado fue que surgió

[u]m proletariado sem consciência, incapaz de formular qualquer pensamento político, com ideias da idade média, pena de morte, homens de bem, a culpa é dos direitos humanos etc. O Brasil do Glauber e do Darcy Ribeiro acabou não rolando e há um bom tempo estou bastante irritado com o triunfo da ignorância, da burrice e da mediocridade (SANT'ANNA apud BRESSANE, 2014).

El escritor destaca que la mayoría de sus narraciones está basada en clichés justamente para explotar esa ignorancia que considera predominante actualmente en el país, por eso repite vertiginosamente los estereotipos, para evidenciar el absurdo y volverlos inaceptables (Maleronka, 2014). "E[]sse discurso pronto [...] expõe todos os preconceitos, todas as verdades políticas e sociais" (SANT'ANNA apud ENTREVISTA, 2008). Para Sant'Anna, las carencias educativas y culturales son parte de un proyecto político elitista y una forma de mantener las desigualdades sociales. Ese es justamente el caso de la primera parte de O Brasil é bom, en que los personajes demuestran su corta visión de mundo y desnudan un país de prohibiciones, conservador e intolerante, incoherente con su pluralidad.

Justamente ese aspecto del conjunto de libros de Sant'Anna es lo que recibe destaque en la crítica literaria. Su escritura es interpretada como una producción peculiar por las narraciones basadas en repeticiones de lugares comunes y prejuicios, 
enunciados por personajes desorientados (SCHOLLHAMMER, 2009, p. 70-77). Esa propuesta estética, con un lenguaje pobre, estilo minimalista y repetitivo, revela personajes acríticos, interpretados como alegorías de una sociedad consumista (DIAS, 2016, p. 37-41) como si fueran máquinas que reproducen ideas vacías (DIAS, 2001, p. 76-77). Estética que se desdobla en planteamientos políticos al criticar impiedosamente las incoherencias de la organización sociopolítica brasileña, principalmente los desarrollos, o la falta de ellos, de las últimas décadas (SILVA, 2017, p. 32-42). Si bien esas interpretaciones ayudan a entender la producción literaria de Sant'Anna, en el caso de O Brasil é bom son insuficientes para explicar la obra, pues en la propuesta estética de este libro, el sentido político y temporal está en la interrelación de las tres partes.

En el primer bloque del libro los personajes están en el presente, totalmente absortos en su propia visión del mundo, incapaces de concebir culturas distintas a las suyas, son adeptos a una única forma de vida, se posicionan contra la diversidad y defienden la violencia para impedirla. La segunda parte, conformada por la narración "Lodaçal", también se pasa en el presente, pero lo que se destaca son las numerosas perspectivas de futuro imaginadas por los personajes, todas pesimistas y miserables. $Y$ en la parte final hay un regreso al pasado, a las memorias autoficcionales, a un tiempo repleto de posibilidades, de experiencias basadas en la diversidad cultural, de proyectos de un país mejor.

El país evocado en la primera parte de O Brasil é bom es actual, intolerante y solamente genera la perspectiva de un porvenir de exclusión social y violencia, que es narrada en la segunda parte. Esas dos imágenes, presente que no ha avanzado y futuro con perspectivas negativas, son el completo opuesto del futuro pretérito, soñado en el tercer bloque. Es como si la estructura del libro estuviera al revés, presente que antecede al pasado, la última parte antes de la primera, propuesta estética que sintetiza bien un Brasil que se volvió lo opuesto de la expectativa que se tenía. Brasil no se volvió un país mejor, no alcanzó la idealización de libertad y mezcla cultural, lo que quedó fue una mentalidad hegemónica de intolerancia.

El autor reconoce que O Brasil é bom es un libro político, una denuncia de la situación del país, del subdesarrollo sumado a los problemas del capitalismo. Sant'Anna asume que la discusión política es fundamental, pero no necesariamente debe ser abordada por la literatura, pues no cree que los libros puedan realizar grandes cambios sociales. Sin embargo, tiene la intención de que sus libros lleguen a 
personas que asimilen sus ideas, reconozcan la banalidad de las relaciones sociales y realicen algún cambio, aunque sea pequeño, y así se pueda construir un mundo más humano (BRASSANE, 2014). A pesar de que el país soñado no llegó a existir, la idea sigue presente, todavía es una aspiración.

\begin{abstract}
Eu quero provocar isso nas pessoas: uma certa indignação com a falta de poesia no mundo. Acho que o mundo poderia ser mais bonito, ter relações mais bonitas entre as pessoas. Deveriam se amar mais. Seria fundir um certo marxismo com o cristianismo. Não um cristianismo no sentido da religião, católico ou evangélico, mas no sentido do amor ao próximo, da convivência entre as pessoas (SANT'ANNA, 2008).
\end{abstract}

Esa intencionalidad es una perspectiva de futuro y en ella está el sentido pragmático del libro, en la transformación social que si bien no alcance a ser el proyecto de Rocha, Ribeiro y Mautner, sigue en busca de un país más plural y libertario. El libro como forma de acción política adquiere relevancia social por el lugar de enunciación ocupado por André Sant'Anna, reconocido por la crítica literaria, publicado por una gran editorial e hijo de un escritor consagrado. Es importante recordar que cuando empezó a recibir atención en el medio literario, el escritor pasó a pensar sus textos direccionados al público especializado (ENTRE-VISTA, 2008). Las ideas expresadas en $O$ Brasil é bom a través de la escritura ficcional, por más que sean obra de un autor, con sus ideologías particulares, son reconocidas institucionalmente en el medio literario. Así, esas ideas se integran a un diálogo social y ganan un sentido político colectivo enfocado en la proyección de una sociedad distinta, en el reconocimiento de que los proyectos de un país libertario, culturalmente democrático y menos capitalista no se realizaron, pero existen en la actualidad como perspectiva.

\title{
Referencias
}

ALMEIDA, T. D'el R.. A crítica de chuteiras: um estudo da Copa de Literatura Brasileira (2007-2009). 2012, Dissertação (Mestrado em Literatura e Cultura), Universidade Federal da Bahia, Salvador.

BRESSANE, R. Sociedade da informação (3). Fluxo, en línea en https://estudiofluxo.squarespace.com/tudo/2014/9/18/sociedade-da-informao-3, entrevista concedida en 18 de septiembre de 2014, acceso en 21 de julio de 2020. 
CARVALHO, B. Amor é esquisito como tudo que ousa inovar. Folha de São Paulo, 18 de abril de 1998.

DIAS, Â. M. Violência e miséria simbólica na cidade de André Sant'Anna. Estudos Históricos. 2001, Rio de janeiro, p. 71-85.

DIAS, A. M.. Histórias do Brasil de André Sant'Anna: sátira, bovarismo e distopia. Brasil Brazil: Revista de Literatura Brasileira. 2016, v. 29, n. 53, p. 36-50.

Entre-vista: André Sant'Anna. Fronteiraz. 2008, v. 1, n. 1, São Paulo, PUC-SP.

HARTOG, F. Regimes de historicidade: presentismo e experiências do tempo. Belo Horizonte: Autêntica, 2013.

KOZEL, A. La Utopía salvaje de Darcy Ribeiro. Nueva Sociedad. 2019, n. 283, p. 126137, en línea, https://nuso.org/articulo/la-utopia-salvaje-de-darcy-ribeiro/, acceso en 20 de julio de 2020.

KOSELLECK, R. Futuro pasado: Para una semántica de los tiempos históricos. Barcelona, Buenos Aires, México: Paidós, 1993.

LORENZ, C. Out of time? Critical reflections on François Hartog presentism. In: TAMM, M.; OLIVIER, L. (eds.). Rethinking historical time: New aproaches to presentism. London, Bloomsbury Academic, 2019.

MALERONKA, A, André Sant'Anna. Vice. Disponível em: https://www.vice.com/pt_br/article/53mk9q/andre-santanna-linguagem-preconceito, entrevista concedida en 02 de diciembre de 2014, acceso en 12 de julio de 2020.

MAUTNER, J. Fundamentos do Kaos. Rio de Janeiro: Azougue Editorial, 1983.

RIBEIRO, D. La civilización emergente. Nueva sociedad. 1984, n. 73, p. 26-37.

ROCHA, G. Eztetyka da fome. Hambre: Espacio Cine Experimental, septiembre de 2013 (1965), en línea, https://hambrecine.com/2013/09/15/eztetyka-da-fome/, acceso en 15 de julio de 2020.

ROCHA, G. Eztetyka do sonho. Hambre: Espacio cine experimental, septiembre de 2013 (1971), disponível em https://hambrecine.com/2013/09/15/eztetyka-do-sonho/, acceso en 15 de julio de 2020.

SANT'ANNA, A. O Brasil é bom. São Paulo: Companhia das Letras, 2014. Archivo Kindle, formato personalizado, fuente Bookerly, tamaño 3.

SANT'ANNA, A. Penetrações. Penetrália, disponível em, http://emiliojunior.zip.net/arch2007-12-30_2008-01-05.html\#2007_12-31_00_07_35125685341-0, 30 de diciembre de 2007.

SCHOLLHAMMER, K. E. Ficção brasileira contemporânea. Rio de Janeiro: Civilização Brasileira, 2009. 
SCHWARZ, R. "Nacional por subtração". In: Que horas são? São Paulo: Companhia das Letras, 1987.

SILVA, A. D. da. Representações irônicas da brasilidade em André Sant'Anna. 2017, tese (Doutorado em Letras), Universidade Federal de Alagoas, Maceió.

SIMON, Zoltán Boldizsár, We have never been presentist: on the regimes of historicity, Blog of Journal of the History of Ideas, 2016, en línea, https://jhiblog.org/2016/05/02/we-have-never-been-presentist-on-regimes-ofhistoricity/, acceso en 22 de julio de 2020.

SÜSSEKIND, F. Toda essa angústia. Jornal do Brasil, 3 de julio de 1999.

TEIXEIRA, J. A horda dos transgressores. Veja, São Paulo, n. 1945, 1 de marzo de 2006.

VASCONCELOS, L. A. L. Estratégias de atuação no mercado editorial: Marcelino Freire e a Geração 90. 2007, Dissertação (Mestrado em Literatura), Universidade de Brasília, Brasília. 